\title{
Evolution of the Freshwater Coastal Current at the Southern Tip of Greenland
}

\author{
Peigen Lin, Robert S. Pickart, ANd Daniel J. TORRes \\ Woods Hole Oceanographic Institution, Woods Hole, Massachusetts
}

ASTRID PACINI

Woods Hole Oceanographic Institution, and MIT-WHOI Joint Program in Physical Oceanography, Woods Hole, Massachusetts

(Manuscript received 2 March 2018, in final form 13 July 2018)

\begin{abstract}
Shipboard hydrographic and velocity measurements collected in summer 2014 are used to study the evolution of the freshwater coastal current in southern Greenland as it encounters Cape Farewell. The velocity structure reveals that the coastal current maintains its identity as it flows around the cape and bifurcates such that most of the flow is diverted to the outer west Greenland shelf, while a small portion remains on the inner shelf. Taking into account this inner branch, the volume transport of the coastal current is conserved, but the freshwater transport decreases on the west side of Cape Farewell. A significant amount of freshwater appears to be transported off the shelf where the outer branch flows adjacent to the shelfbreak circulation. It is argued that the offshore transposition of the coastal current is caused by the flow following the isobaths as they bend offshore because of the widening of the shelf on the west side of Cape Farewell. An analysis of the potential vorticity shows that the subsequent seaward flux of freshwater can be enhanced by instabilities of the current. This set of circumstances provides a pathway for the freshest water originating from the Arctic, as well as runoff from the Greenland ice sheet, to be fluxed into the interior Labrador Sea where it could influence convection in the basin.
\end{abstract}

\section{Introduction}

South of the Denmark Strait, the East Greenland boundary current system consists of a complex set of currents ranging from the inner shelf to the base of the continental slope (Fig. 1). The densest, offshore-most component is the deep western boundary current (DWBC) that advects recently ventilated overflow water equatorward (Dickson and Brown 1994). Farther up the slope is the East Greenland Spill Jet, which is formed by dense water cascading off the shelf south of the Denmark Strait (Pickart et al. 2005; Brearley et al. 2012; von Appen et al. 2014). In the vicinity of the shelf break, the East Greenland Current (EGC) merges with the recirculating portion of the Irminger Current (IC) to form a single flow that is often referred to as the East Greenland Current/Irminger Current (EGC/IC; Sutherland and Pickart 2008). This combined current is the upstream source of the shelfbreak jet that flows more or less continuously all the way to the Gulf Stream separation point (Fratantoni and Pickart 2007). Finally, on the inner shelf, the East Greenland Coastal Current (EGCC)

\footnotetext{
Corresponding author: Peigen Lin, plinwhoi@gmail.com
}

advects cold, freshwater equatorward toward Cape Farewell (Bacon et al. 2002; Sutherland and Pickart 2008).

The EGCC is a major conduit of freshwater from the Nordic seas and high Arctic into the North Atlantic (e.g., Rudels et al. 2002, 2005; Pickart et al. 2005; Jones et al. 2008). Based on a series of observational, modeling, and laboratory studies, its basic features are now fairly well established. The current is surface intensified (but often extending to the bottom), of order $15-25 \mathrm{~km}$ wide, with core speeds that can at times exceed $0.5 \mathrm{~m} \mathrm{~s}^{-1}$ (Bacon et al. 2002; Pickart et al. 2005; Sutherland and Pickart 2008; Harden et al. 2014). Synoptic shipboard estimates of its volume transport vary considerably, ranging from $0.3-2.0 \mathrm{~Sv}$ ( $1 \mathrm{~Sv} \equiv 10^{6} \mathrm{~m}^{3} \mathrm{~s}^{-1}$; Fig. 2). Some of this variability is wind driven (Sutherland and Pickart 2008; Harden et al. 2014), associated with the barrier flow adjacent to the Greenland coast. Nonetheless, there is a tendency of increased transport between the Denmark Strait and Cape Farewell (Fig. 2). It must be kept in mind that most of the shipboard data were obtained in the summer months. While year-long mooring data indicate seasonal variability in the hydrographic properties of the current (Harden et al. 2014), to date no mooring arrays have been 


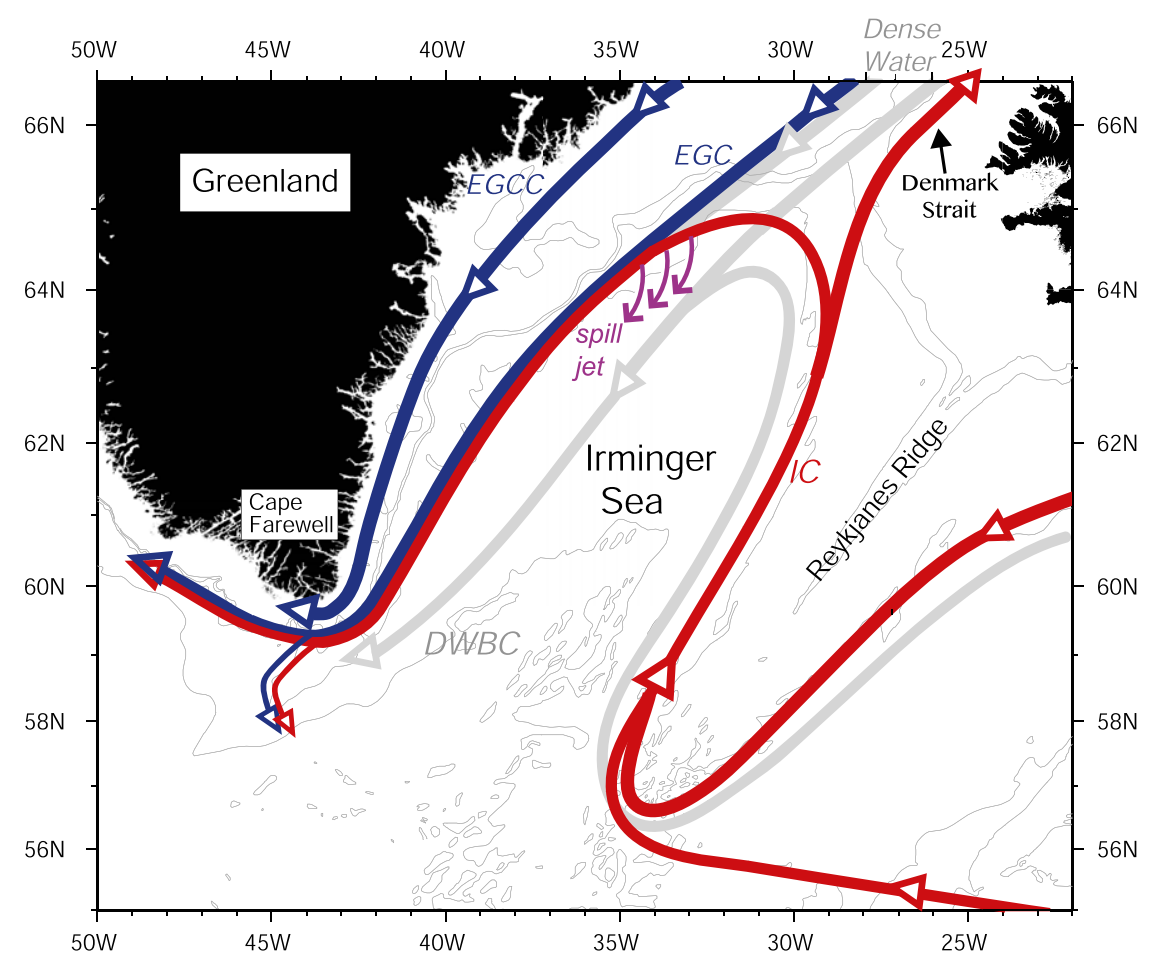

FIG. 1. Schematic circulation of the boundary currents in the Irminger Sea after Brearley et al. (2012).

deployed that capture its full transport. The model study of Bacon et al. (2014) suggests that the EGCC has a pronounced annual cycle in transport, with nearly twice the equatorward volume flux in winter versus summer.

Although the existence of the EGCC is now well established, there remains considerable uncertainty regarding the current's origin and fate. Bacon et al. (2002) suggested that the EGCC results predominantly from meltwater and runoff from Greenland. Sutherland and Pickart (2008), on the other hand, argued that the current is formed mainly via a bifurcation of the EGC/IC just south of the Denmark Strait. Considering the shelfbreak jet and the coastal current as a single system was the only way that Sutherland and Pickart (2008) could balance mass with their shipboard measurements. The laboratory experiments of Sutherland and Cenedese (2009) provide a dynamical explanation for why part of the EGC/IC should get diverted to the inner shelf as the current encounters the Kangerdlugssuaq Trough south of the Denmark Strait. Of course, the explanations of Bacon et al. (2002) and Sutherland and Pickart (2008) are not mutually exclusive, although the mooring measurements of Harden et al. (2014) suggest that the seasonality of the EGCC's freshwater signal is predominantly due to outflow from the Arctic instead of local runoff.

Complicating matters further is the fact that a coastal current has been identified north of the Denmark Strait as well. This was first reported by Nilsson et al. (2008) and recently confirmed by Håvik et al. (2017). The three shipboard sections analyzed by Håvik et al. (2017) that extended well onto the Greenland shelf revealed a freshwater jet with a similar velocity structure and hydrographic characteristics to the EGCC south of the Denmark Strait. Furthermore, the range in volume transports reported by Håvik et al. (2017) are in line with those found farther south. Observations within the Denmark Strait will be necessary to demonstrate any continuity between the coastal jet north and south of the strait.

Summertime freshwater transport estimates for the EGCC range from 10 (Dickson et al. 2007) to $100 \mathrm{mSv}$ (Wilkinson and Bacon 2005). Bacon et al. (2002) noted that their estimate of $60 \mathrm{mSv}\left(1 \mathrm{mSv}=10^{3} \mathrm{~m}^{3} \mathrm{~s}^{-1}\right)$ is close to $30 \%$ of the annual net Arctic freshwater input given by Dickson et al. (2007). ${ }^{1}$ This value, which is also comparable to the freshwater flux computed by Sutherland and Pickart (2008), is significantly larger than the freshwater contribution of the Alaskan Coastal Current to the Arctic

\footnotetext{
${ }^{1}$ Bacon et al.'s (2002) freshwater estimate used a reference salinity of 34.956 . When referencing to a value of 34.8 , which is more commonly used in the literature, their estimate is increased by roughly 15\% (Sutherland and Pickart 2008).
} 


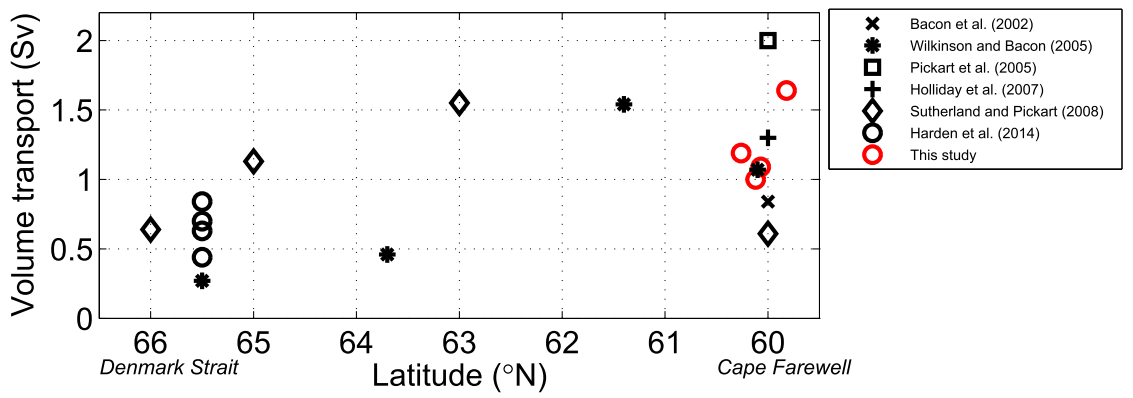

FIG. 2. Volume transport estimates of the EGCC, between the Denmark Strait and Cape Farewell, from the available literature (see the legend). The values from the present study are indicated by the red circles.

( $\sim 14 \mathrm{mSv}$; Woodgate et al. 2005). The recent freshwater budget for the Arctic Ocean constructed by Haine et al. (2015) quotes a value of $2800 \pm 420 \mathrm{~km}^{3} \mathrm{yr}^{-1}$ for the liquid freshwater export through the Fram Strait. The range of EGCC values noted above (which converts to $300-3100 \mathrm{~km}^{3} \mathrm{yr}^{-1}$ ) suggests that a substantial portion of the Fram Strait export could end up in the coastal current. In addition, multiyear sea ice originating from the Arctic Ocean accounts for a large amount of the outflowing freshwater that reaches the west side of Greenland, although it is not generally significant in summer (Buch 2002; Schmith and Hansen 2003).

The downstream fate of the EGCC is equally uncertain at this point. Drifter data from the World Ocean Circulation Experiment (WOCE) Surface Velocity Program imply that the EGCC merges with the EGC/IC near Cape Farewell (Bacon et al. 2002; Centurioni and Gould 2004). This is consistent with the shipboard data reported by Holliday et al. (2007). They suggested that the merged coastal current and shelfbreak jet form the West Greenland Current, a portion of which retroflects toward the central Irminger Basin (Fig. 1). Long-term historical observations reveal that the West Greenland Current continues poleward, carrying the low-salinity water along with the warmer and saltier Irminger water offshore (Buch 2000). There is, however, no existing evidence from shipboard measurements or drifter data of a separate coastal current (Cuny et al. 2002).

It is of high importance to determine the fate of the freshwater in the EGCC. This is especially true in light of the increasing glacial melt from Greenland (Hanna et al. 2008), which flows directly into the coastal current. The Labrador Sea is a major site of convective overturning that influences the stratification of the subpolar North Atlantic (e.g., Talley and McCartney 1982; Yashayaev et al. 2007) as well as the middepth component of the meridional overturning circulation (Talley et al. 2003). The surface freshwater in the Labrador Sea can act as a barrier to the convection by modulating the stratification and heat loss to the atmosphere (e.g., Lazier 1980; Bailey et al. 2005; Hátún et al. 2007). Hence, one needs to determine the sources and timing of freshwater to the interior Labrador Sea. Numerical and observational studies have argued that the West Greenland Current is the major contributor of freshwater to the Labrador Basin (Myers 2005; Straneo 2006) and is predominantly responsible for both the seasonal and interannual variability (Schmidt and Send 2007). The factors influencing the salinity of the West Greenland Current are a combination of advection from upstream (Rykova et al. 2015) and local sea ice melt (Myers et al. 2009).

The present study investigates the kinematics, dynamics, water mass characteristics, and transport of the coastal current as it rounds Cape Farewell, progressing from the east Greenland shelf to the west Greenland shelf. The overall aim is to shed light on the evolution of the current and the fate of the freshwater that it transports. We use data from a cruise that was carried out in August 2014, which included eight highresolution sections in the vicinity of Cape Farewell. We begin with a description of the shipboard data and the definition used to isolate the coastal current. We then present the statistics of the current, highlighting the differences on the two sides of Greenland. Finally, we address the offshore flux of freshwater from the current and possible mechanisms driving this, including the role of the bathymetry and the dynamics of the circulation.

\section{Data and methods}

\section{a. Observations}

The main source of data used in this study is from an August 2014 cruise on the Research Vessel (R/V) Knorr, carried out as part of the Overturning in the Subpolar North Atlantic Program (OSNAP). There were eight sections occupied across the east and west Greenland shelves around Cape Farewell (Fig. 3). In all but one case (section $\mathrm{k} 3$ ), the innermost station was 


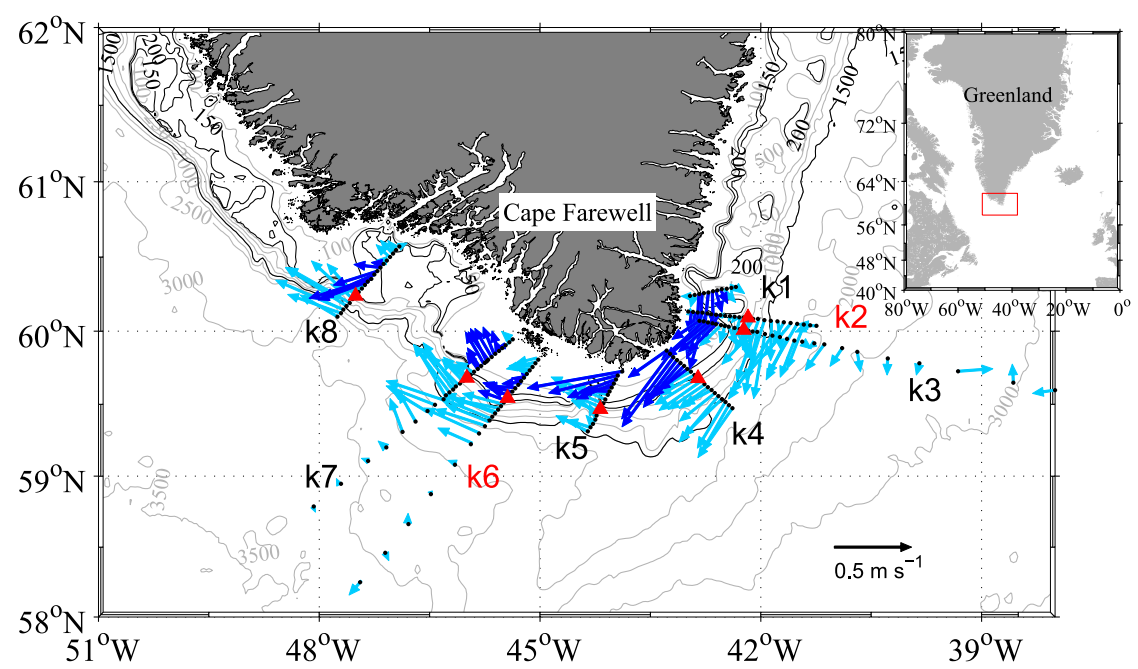

FIG. 3. The eight shipboard sections (k1-k8) carried out during the August 2014 Knorr cruise (sections $\mathrm{k} 2$ and $\mathrm{k} 6$ are highlighted, as they are considered in detail later in the text). The CTD station positions are marked by the black dots. The vertically averaged ADCP velocity vectors for each of the transects are shown. The dark blue vectors denote the Greenland Coastal Current using the definition in the text. The red triangles mark the location of the shelf break for each section as determined by the shipboard echosounder data. The bathymetry is from ETOPO2v2, where the 150-, 200-, and 1500-m isobaths are highlighted.

occupied as close to shore as permitted by the vessel, and except for section $\mathrm{k} 1$, each of the lines extended across the shelf break onto the continental slope. A conductivitytemperature-depth (CTD) cast was done at each station using a Sea-Bird $911+$ system on a 24-place rosette with $10-\mathrm{L}$ bottles. The thermistors underwent laboratory calibrations pre- and postcruise, and the conductivity sensors were further calibrated using water sample salinity data. The accuracy of the CTD measurements were deemed to be $0.001^{\circ} \mathrm{C}$ for temperature, 0.002 for salinity, and $0.3 \mathrm{db}$ for pressure.

Velocity data were obtained using Knorr's hullmounted Teledyne RD Instruments $75-$ and $300-\mathrm{kHz}$ acoustic Doppler current profilers (ADCPs). In this study, we used predominantly the lower-frequency data. The 75-kHz ADCP was set up to collect 128 8-m bins in narrowband mode at a ping rate of approximately one ping per two seconds. We note that there is a blanking region with no ADCP data in roughly the top $10 \mathrm{~m}$ of the water column, and, on the shelf, in the near-bottom layer (approximately $15 \%$ of the water depth). The data were acquired using the University of Hawaii Data Acquisition System (UHDAS) and subsequently processed using the Common Ocean Data Access System (CODAS; Firing and Hummon 2010). The ship's gyro heading was corrected using an Applanix position and orientation system for marine vessels GPS/internal measurement unit heading correction system. A transducer heading misalignment calibration was applied to the
ADCP heading data as well. Instrument measurement errors were reduced by editing the single-ping data prior to averaging the final data into 5-min ensembles. The velocity profiles were then detided using the Oregon State University TOPEX/Poseidon $1 / 12^{\circ}$-resolution Atlantic Ocean regional barotropic tidal model (Egbert and Erofeeva 2002). The resulting uncertainty in the velocity data, due to instrument and tidal model errors, is estimated to be $0.02-0.03 \mathrm{~m} \mathrm{~s}^{-1}$ (see Våge et al. 2011 for details).

Vertical sections of hydrographic variables for each transect were constructed using a Laplacian-spline interpolation routine, with a horizontal grid spacing ranging from 2 to $5 \mathrm{~km}$ and vertical grid spacing of $10 \mathrm{~m}$. The variables considered were potential temperature and potential density referenced to the sea surface. Absolute geostrophic velocities were computed by referencing the thermal wind shear to the ADCP velocities. Specifically, interpolated sections of thermal wind shear were referenced to interpolated sections of cross-track ADCP velocity at each grid point, where the matching was done over the common depth range of the two measurements. This approach has been used in many previous studies (e.g., Pickart and Spall 2007; Våge et al. 2013; Håvik et al. 2017). Because of the blanking region of the ADCP, this avoids the near-surface and near-bottom layers, and by using a range of depths, this reduces the impact of any spurious ADCP values. Vertical sections of absolute geostrophic velocity were then constructed, as were 
sections of Ertel potential vorticity (see section 6 for a presentation of the potential vorticity).

A $12-\mathrm{kHz}$ Knudsen echosounder provided highresolution bottom depth data along each section. Using these data, we objectively identified the location of the shelf break along each transect as the point corresponding to the largest along-section gradient of the bottom slope. This was done by differencing the depth at each point with the depth at the innermost point (which serves to avoid issues due to isolated anomalous features in the bathymetry). The distance to shore at the innermost stations for sections $\mathrm{k} 1-\mathrm{k} 7$ was obtained using the radar during a 2016 OSNAP cruise that repeated these sections (for section $\mathrm{k} 8$, we estimated this distance using a chart).

Measurements of in situ wind speed and direction were obtained at 1-min intervals using Knorr's meteorological systems on the port and starboard sides of the ship. The true wind vectors were computed using the Shipboard Automated Meteorological and Oceanographic System.

\section{b. Definition of the Greenland Coastal Current}

Previous studies have used different criteria to define the location and width of the EGCC. Wilkinson and Bacon (2005) used the 33.5 isohaline to denote the outer edge of the flow and determined a "best correlation" between the depth of the 33.5 isohaline and the transport of the current. Farther upstream, Harden et al. (2014) used the 34 isohaline as the edge of EGCC, arguing that this best represented the boundary between the polar-origin and Atlantic-origin waters. Sutherland et al. (2009) considered both salinity and velocity to define the EGCC. The lateral range of the current was taken to be where the velocity is $15 \%$ of the peak value, and the vertical scale defined as the depth where the 34 isohaline intersects the bottom.

Here we define the Greenland Coastal Current based only on the velocity structure. The lateral range corresponds to $15 \%$ of the peak along-shelf velocity (following Sutherland and Pickart 2008), and the vertical scale is taken to be the depth of the zero crossing in velocity or the bottom depth. Based on tests using representative sections, we verified that our results and conclusions are not sensitive to the details of this definition. While there are quantitative differences in the resulting volume and freshwater transports, the trends remain unchanged. The along-shelf direction is perpendicular to each transect (positive equatorward) and the cross-shelf direction is parallel to each transect (positive offshore).

\section{Characteristics of the Greenland Coastal Current}

Using the ADCP data, we constructed a lateral map of vertically averaged flow over the upper $200 \mathrm{~m}$ (Fig. 3; where on the shelf the average is over the depth range of the ADCP data, see section 2a). The location of the shelf break at each line is marked by the red triangle. One sees that the coastal current (indicated by the dark blue vectors) flows adjacent to the east coast and southern tip of Greenland (sections k1-k5) inshore of the shelf break. However, at section k5, the coastal current is directed offshore, and at the next section (k6) it is found at the edge of the shelf. Downstream of k6 it shifts back onshore (this interpretation is supported by Fig. 10; see section 5 below). Note that at the three final sections there is still along-shelf flow close to shore, but it is too weak to fit our definition of the coastal current. This is in contrast to the east side of Greenland where the flow remains strong right up to the inshore-most station.

Using the ADCP vectors as a guide, we constructed a schematic of the circulation in the vicinity of Cape Farewell (Fig. 4). The shelfbreak current (red line) transitions from the East Greenland Current to the West Greenland Current. This includes the Irminger Current portion, which advects warm and salty subtropicalorigin water equatorward. Rather than merging with the shelfbreak jet to form the West Greenland Current, as suggested by previous studies, our data indicate that the coastal current briefly interacts with the shelfbreak jet but tends shoreward again as it flows northward. As such, we contend that the coastal current maintains its identity and refer to it as the West Greenland Coastal Current (WGCC). As mentioned above, the WGCC appears to bifurcate where it is first diverted offshore, with a small branch flowing along the inner shelf.

The basic characteristics of the coastal current as it flows around Cape Farewell (sections $\mathrm{k} 1-\mathrm{k} 4$ as the EGCC, $\mathrm{k} 5-\mathrm{k} 8$ as the WGCC) are listed in Table 1. One should keep in mind that the sections $\mathrm{k} 3, \mathrm{k} 4$, and $\mathrm{k} 5$, on the east side of Greenland and the southern tip, did not completely capture the inner part of the coastal current. This is true despite the fact that, except for section $\mathrm{k} 3$, the inshore-most stations were very close to shore (Table 1). We estimated the missing coastal current transport at these three sections by fitting a Gaussian curve to the depth-averaged velocity and assuming the bottom depth varied linearly from the value at the innermost station to zero at the coast. The resulting transports were very small (smaller than the standard deviation of the overall average transport). The mean width of the coastal current over all sections is $22.1 \pm 4.5 \mathrm{~km}$, consistent with previous studies. The maximum along-shelf velocity in the core of the current varies from 0.33 to $1.10 \mathrm{~m} \mathrm{~s}^{-1}$, with generally smaller values on the west side of Greenland. This results in a decrease in transport of the WGCC versus the EGCC. Notably, however, when taking into account the small bifurcated branch of the WGCC (bracketed values 


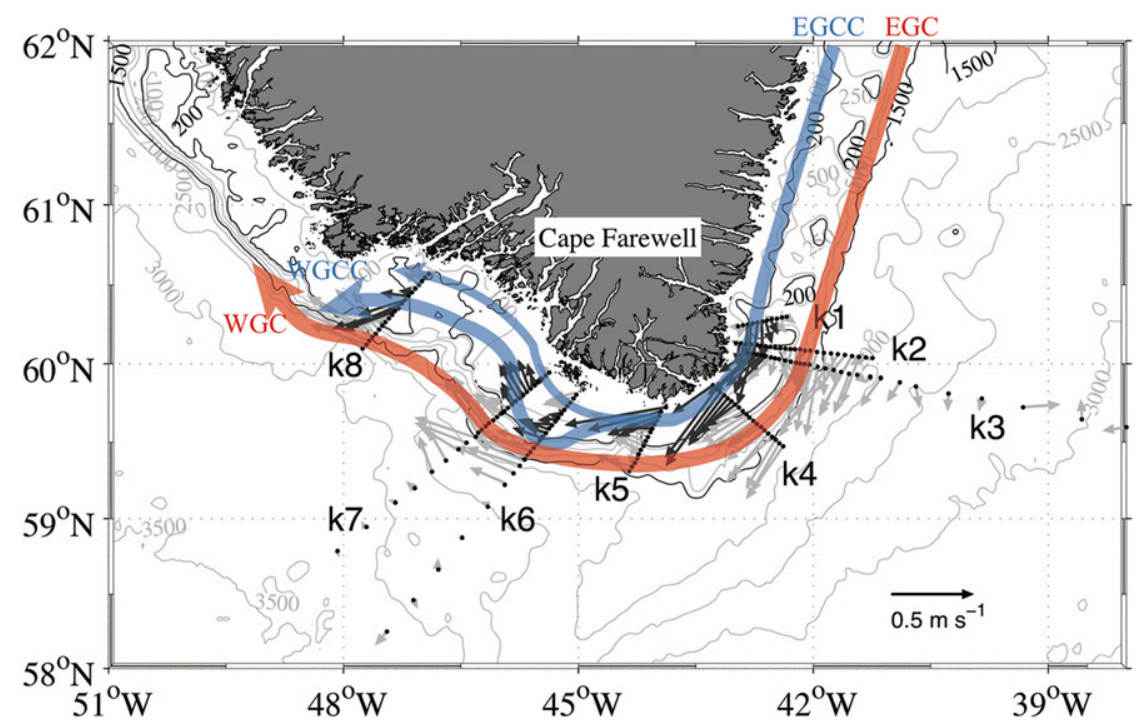

FIG. 4. Schematic flow lines representing the Greenland boundary current system during the survey. The blue and red lines correspond to the coastal current and shelfbreak circulation, respectively. The flow lines are overlain on the depth-averaged ADCP flow vectors from Fig. 3, where the black vectors denote the Greenland Coastal Current.

in Table 1), the volume transport of the total coastal flow is essentially conserved as it rounds Cape Farewell (there is a drop at the last section, $\mathrm{k} 8$ ). The overall mean transport of both branches of the coastal current is $1.09 \pm$ $0.26 \mathrm{~Sv}$, in line with previous studies (Fig. 2).

Following the method of Håvik et al. (2017), we computed the along-shelf freshwater transport of the coastal current for each section using a reference salinity of 34.8. (Since there was no pack ice present during the survey, and only a sparse number of icebergs, we can neglect the frozen component of freshwater.) As with the volume transport, the freshwater transport of the EGCC is larger than that of the WGCC (the exception being the underestimated value at $\mathrm{k} 3$, because this section did not extend as close to shore). However, even when accounting for the inner-shelf branch on the western side of Greenland, the freshwater transport is still smaller than on the eastern side. Our data suggest then that the coastal flow loses approximately $20 \mathrm{mSv}$ of freshwater as it rounds Cape Farewell, a 29\% decrease. This raises the question, what drives this loss and where does the freshwater go?

\section{Interaction of the Greenland Coastal Current with the shelfbreak flow}

The decrease of freshwater flux on the west side of Greenland motivates us to delve more closely into the factors resulting in this loss and the potential consequences. Fortunately, some of the sections extended into the basin (see Fig. 2) allowing us to investigate more extensively the full boundary current system on either side of Greenland. We now consider two transectssection k2 east of Cape Farewell $(\sim 100 \mathrm{~km}$ long$)$ and section k6 west of Cape Farewell $(\sim 220 \mathrm{~km})$. Note that $\mathrm{k} 6$ is located where the coastal current abuts the shelfbreak current (Fig. 4).

As reported in many previous studies, there are three types of water masses in the east Greenland boundary current system: Arctic-origin water, Atlantic-origin water, and deep overflow water (e.g., Rudels et al. 2002; Holliday et al. 2007; Sutherland and Pickart 2008). Arcticorigin water consists of polar surface water and polar intermediate water, where the former originates from the mixed layer in the Arctic Ocean, and the latter stems from the Arctic Ocean thermocline in the depth range of 150-200 m (Friedrich et al. 1995; Rudels et al. 1999). Rudels et al. (2002) further reported that melting sea ice can form a warmer type of polar surface water. There are two varieties of Atlantic-origin water. The warmest and most saline type is the water that recirculates in the Irminger Sea and joins the East Greenland Current (Holliday et al. 2007; see Fig. 1), while colder and fresher Atlantic-origin water is advected into the Irminger Sea from the Iceland Sea via the East Greenland Current (e.g., Håvik et al. 2017). Finally, the cold and dense Denmark Strait overflow water is found below the Atlantic-origin water (e.g., Cuny et al. 2002).

The above water mass classifications are not completely applicable in the vicinity of Cape Farewell. For this reason, we have identified the water types observed 
TABLE 1. Characteristics of the Greenland Coastal Current as it rounds Cape Farewell: EGCC (k1-k4) and WGCC (k5-k8). The bracketed values in k6-k8 denote the transports including the inner-shelf branch.

\begin{tabular}{|c|c|c|c|c|c|}
\hline Sections & $\begin{array}{l}\text { Distance to land of the } \\
\text { inshore-most station }(\mathrm{km})\end{array}$ & Width $(\mathrm{km})$ & $\begin{array}{l}\text { Peak along-shelf } \\
\text { velocity }\left(\mathrm{m} \mathrm{s}^{-1}\right)\end{array}$ & $\begin{array}{l}\text { Along-shelf volume } \\
\text { transport }(\mathrm{Sv})\end{array}$ & $\begin{array}{c}\text { Along-shelf freshwater } \\
\text { transport }(\mathrm{mSv})\end{array}$ \\
\hline \multicolumn{6}{|l|}{ EGCC } \\
\hline k1 & 5.96 & 24 & 0.81 & 1.19 & 75.07 \\
\hline $\mathrm{k} 2$ & 4.00 & 20 & 1.10 & 1.00 & 68.45 \\
\hline $\mathrm{k} 3$ & 12.26 & 15 & 0.74 & 1.09 & 40.95 \\
\hline $\mathrm{k} 4$ & 5.34 & 22 & 1.02 & 1.64 & 79.46 \\
\hline $\operatorname{Mean}^{\mathrm{a}}$ & $5.10 \pm 1.00$ & $22.00 \pm 2.00$ & $0.98 \pm 0.15$ & $1.28 \pm 0.33$ & $74.33 \pm 5.54$ \\
\hline \multicolumn{6}{|l|}{ WGCC } \\
\hline $\mathrm{k} 5$ & 5.89 & 19 & 0.70 & 1.01 & 49.50 \\
\hline k6 & 8.58 & 25 & 0.74 & $0.85[1.06]$ & $40.04[54.44]$ \\
\hline $\mathrm{k} 7$ & 7.85 & 30 & 0.48 & $0.87[0.94]$ & $49.16[54.02]$ \\
\hline $\mathrm{k} 8$ & - & 22 & 0.33 & $0.42[0.78]$ & $23.32[37.78]$ \\
\hline Mean $^{a}$ & $7.44 \pm 1.39$ & $24.67 \pm 5.50$ & $0.64 \pm 0.14$ & $1.00 \pm 0.06$ & $52.65 \pm 2.74$ \\
\hline
\end{tabular}

${ }^{\mathrm{a}}$ Sections $\mathrm{k} 3$ and $\mathrm{k} 8$ are excluded from the averages (see text for details). The inner-shelf branch is included in the mean volume transport and freshwater transport of the WGCC.

in our 2014 survey using the following simple scheme (see Fig. 5): surface Arctic-origin water (SArW), deep Arctic-origin water (DArW), upper Atlantic-origin water (UAtW), deep Atlantic-origin water (DAtW), overflow water $(\mathrm{OW})$, and mixed water (MW), which is a mixture of Arctic-origin and Atlantic-origin waters. Following Sutherland and Pickart (2008), we used $S=$ 34.8 as the boundary between the Atlantic-origin water and Arctic-origin water, which is also the reference salinity used for freshwater transport calculations. The volumetric temperature-salinity $(\theta-S)$ diagram shown in Fig. 5 reveals that, not surprisingly, most of the water in each transect is Atlantic-origin water. There is evidence of a mixing line between this water and the deep Arctic-origin water, as well as a mixing line between Atlantic-origin water and surface Arctic-origin water. Finally, a mixing line is evident between the surface and deep Arctic-origin waters.

The distribution of properties in the vertical plane at transects $\mathrm{k} 2$ and $\mathrm{k} 6$ highlights some of the differences between the two sides of Greenland (Fig. 6). On the shelf, both sections contain surface Arctic-origin water atop deep Arctic-origin water. However, on the east side of Greenland, the wedge of coldest/freshest water is adjacent to the coast, forming a front well inshore of the shelf break, compared to the west side of Greenland where the wedge extends to the outer shelf. The signature of Atlantic-origin water offshore is also different in the two sections. In particular, both the upper and deep Atlantic-origin waters are warmer and saltier on the east side of Greenland.

One notable difference between $\mathrm{k} 2$ and $\mathrm{k} 6$ seaward of the shelf break is the layer of near-surface freshwater that extends into the interior at section k6. In Figs. 6e and $6 f$ we have marked the portion of the water column where $S<34.8$ (gray dots in the figure). One sees that the freshwater is present in the upper $50 \mathrm{~m}$ (potential density $<27.0 \mathrm{~kg} \mathrm{~m}^{-3}$ ) all the way to the offshore end of $\mathrm{k} 6$. This is consistent with the enhanced stratification of this buoyant layer (cf. Fig. 6e with Fig. 6f). By contrast, the 27.0 isopycnal outcrops near the shelf break at section $\mathrm{k} 2$ (this is true as well at section $\mathrm{k} 3$ on the east side of Greenland, not shown).

The vertical sections of absolute geostrophic velocity for transects $\mathrm{k} 2$ and $\mathrm{k} 6$ show that, even though the coastal current has transitioned from the inner shelf to the outer shelf as it rounds Cape Farewell, in both locations it is distinguishable from the shelfbreak current

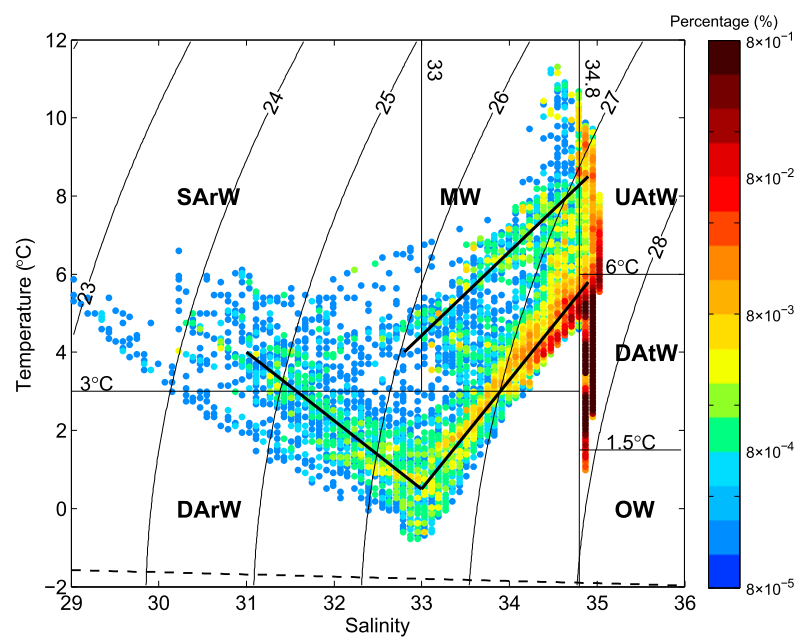

FIG. 5. Volumetric $\theta-S$ diagram for the stations in transects k2 and $\mathrm{k} 6$, where the color represents the percentage of data in each grid cell of $0.08^{\circ} \mathrm{C}$ temperature by 0.08 salinity. The different water types are denoted by the boxes, where the bounding values of temperature and salinity are labeled. 

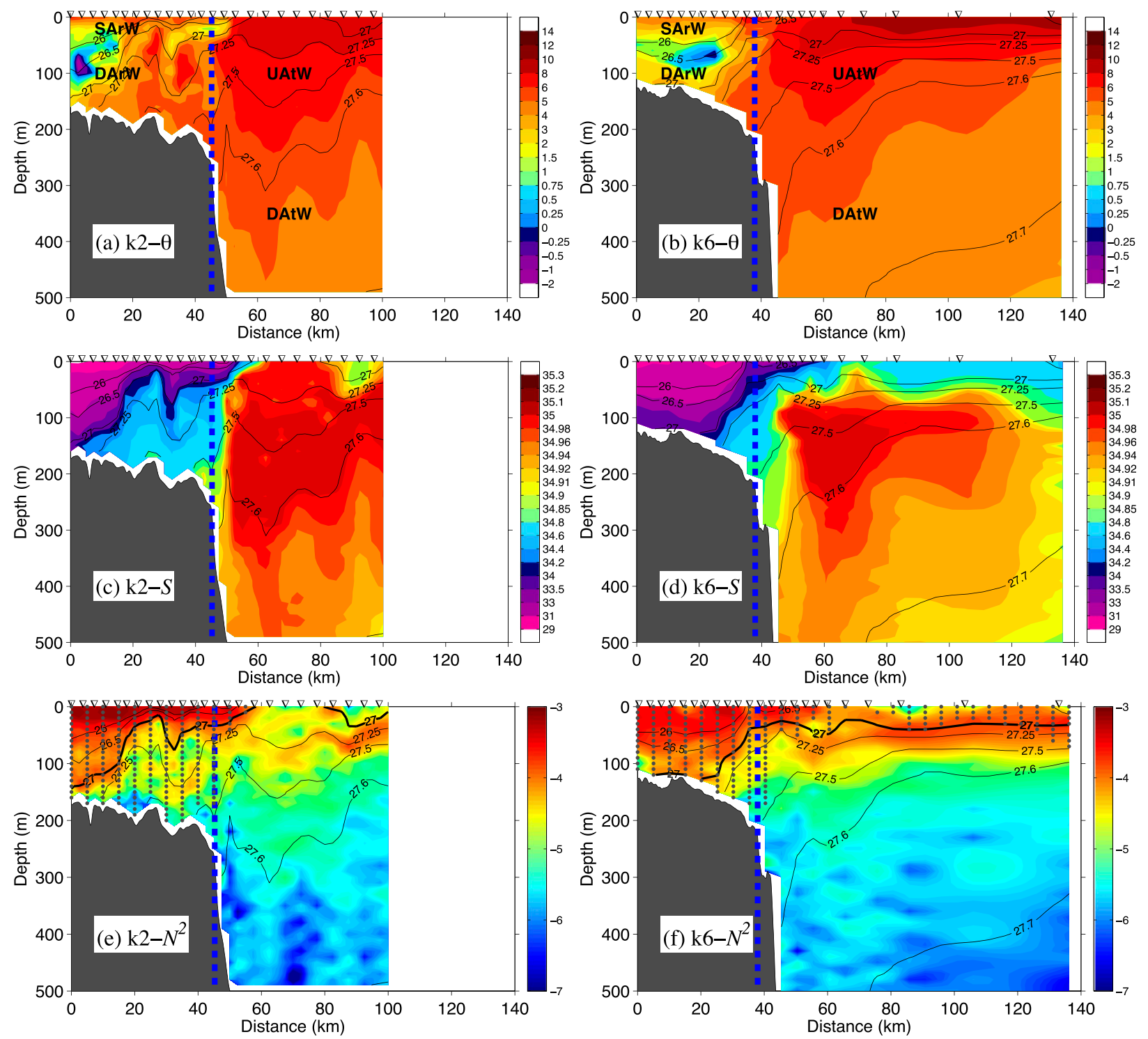

FIG. 6. Sectional distributions of (a),(b) potential temperature $\left({ }^{\circ} \mathrm{C}\right) ;(\mathrm{c}),(\mathrm{d})$ salinity; and (e),(f) buoyancy frequency $\left[\log _{10}\left(N^{2}\right) ; \mathrm{s}^{-2}\right]$ overlaid by potential density (contours) in sections (left) $\mathrm{k} 2$ and (right) $\mathrm{k} 6$. The inverted triangles indicate the station locations, and the red lines denote the shelfbreak locations. In (e) and (f) the freshwater $(S<34.8)$ distribution is marked by gray dots, and the isopycnal $27.0 \mathrm{~kg} \mathrm{~m}^{-3}$ is highlighted.

(Fig. 7). There is, however, evidence of exchange between the two flows at section k6. The layer of freshwater in the interior, noted above, corresponds to the mixed water type identified in Fig. 5. In particular, it is the water along the mixing line between the upper Atlantic-origin water and the surface Arctic water. All instances of this mixed water are marked by gray dots on the vertical sections of velocity in Fig. 7. While this water is present seaward of the shelf break on the west side of Greenland, it is virtually absent on the east side.

This same information is presented in $\theta-S$ space in Fig. 8 , where the water along the upper mixing line is delineated by the ellipse in the figure. There are very few points within this region at $\mathrm{k} 2$, while at $\mathrm{k} 6$ there are quite a few associated with the equatorward flow of the boundary current system. These results suggest that although the WGCC and shelfbreak current do not merge near Cape Farewell, they interact with each other, which enhances mixing and exchange of Arctic-origin and Atlantic-origin water masses. This results in a flux of freshwater into the interior of the Labrador Sea.

The veering of the coastal current from the inner shelf to the outer shelf is also highlighted by considering the cross-shelf component of flow from the ADCP data. For 

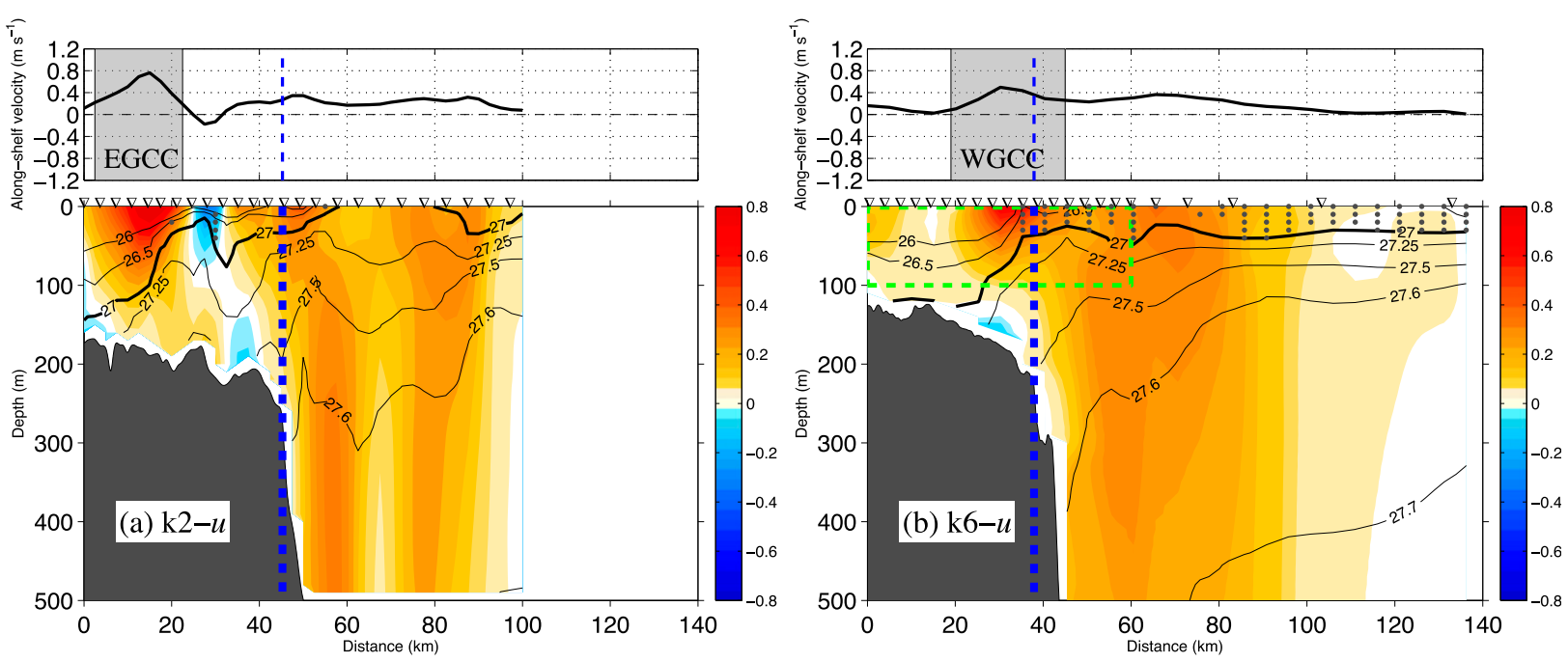

FIG. 7. Absolute geostrophic velocity for sections (left) k2 and (right) k6. (top) The mean velocity over the top $10 \mathrm{~m}$ and (bottom) the vertical sections, where the velocity is in color $\left(\mathrm{m} \mathrm{s}^{-1}\right)$ and density is contoured $\left(\mathrm{kg} \mathrm{m}^{-3}\right)$. The approximate range of the coastal current is shaded in the top panels, and the blue dashed lines denote the location of the shelf break. CTD stations are marked by the inverted triangles. The distribution of MW of SArW and UAtW is marked by gray dots. The dashed green box in the bottom-right panel delimits the region considered for the potential vorticity analysis of section 6 (see Fig. 11).

each transect we computed the cross-shelf volume and freshwater transports per unit width, averaged over the coastal current (Fig. 9). For the four sections on the east side of Greenland, the cross-shelf transports are negative or close to zero. However, at k5 near the tip of Cape Farewell, the transports are strongly offshore (which is evident in the vector plot of Fig. 3). They remain offshore (but not as large) at the next section as well, where the coastal current abuts the shelfbreak flow. Then at $\mathrm{k} 7$, the transports are negative as the current deflects back onto the central shelf. (The flow at the last section is directed offshore again, but the complex topography at this location makes it difficult to interpret this.) We now explore possible mechanisms that cause the coastal current to transpose to the outer shelf as it rounds Cape Farewell.

\section{Potential mechanisms driving the separation of the coastal current}

There are several possible reasons behind the observed transposition of the Greenland Coastal Current from the inner shelf to the outer shelf at Cape Farewell, leading to the enhanced shelf-basin exchange there. We now consider three different possibilities.

\section{a. Wind forcing}

Following Whitney and Garvine (2005), we calculated a wind strength index $W_{s}$, which is a measure of the extent to which a current is wind driven versus buoyancy driven,

$$
W_{s}=u_{\text {wind }} / u_{\text {buoy }}=\left(\sqrt{\frac{\rho_{\text {air }}}{\rho} \frac{C_{10}}{C_{D}}} U\right) /\left[\frac{\left(2 g^{\prime} Q f\right)^{-4}}{K}\right],
$$

where $\rho_{\text {air }}$ and $\rho$ are the air and water density, respectively, $C_{10}$ is the surface atmospheric drag coefficient, $C_{D}$ is the drag coefficient at the seafloor, $U$ is the wind speed, $g^{\prime}$ is the reduced gravity, $f$ is the Coriolis parameter, $Q$ is the volume transport of the current, and $K$ is the dimensionless current width. When $\left|W_{s}\right|>1$ the current is predominantly wind driven, otherwise buoyancy forcing plays an essential role. Using the shipboard wind and hydrographic measurements, we evaluated (1) at each transect, and in all cases $\left|W_{s}\right|<1$ (the range was from 0.05 to 0.41 , with a mean of 0.18 ). This implies that the coastal current is predominantly buoyancy driven, in line with the results of Sutherland and Pickart (2008). Also, Ekman velocities during the cruise were on the order of $10^{-3} \mathrm{~m} \mathrm{~s}^{-1}$, far less than the ADCP measurements. As such, it is unlikely that wind played a role in the separation of the coastal current.

\section{b. Curvature of Cape Farewell}

Another possible factor that could lead to separation is the curvature of the coastline around Cape Farewell. Previous studies have shown that, for a small enough value of the curvature, a current will not stay attached to the coast. Separation occurs when the inertial radius of the current $u / f$, where $u$ is the current velocity, is larger than the radius of curvature of the cape (Klinger 1994). This has also been determined by laboratory 

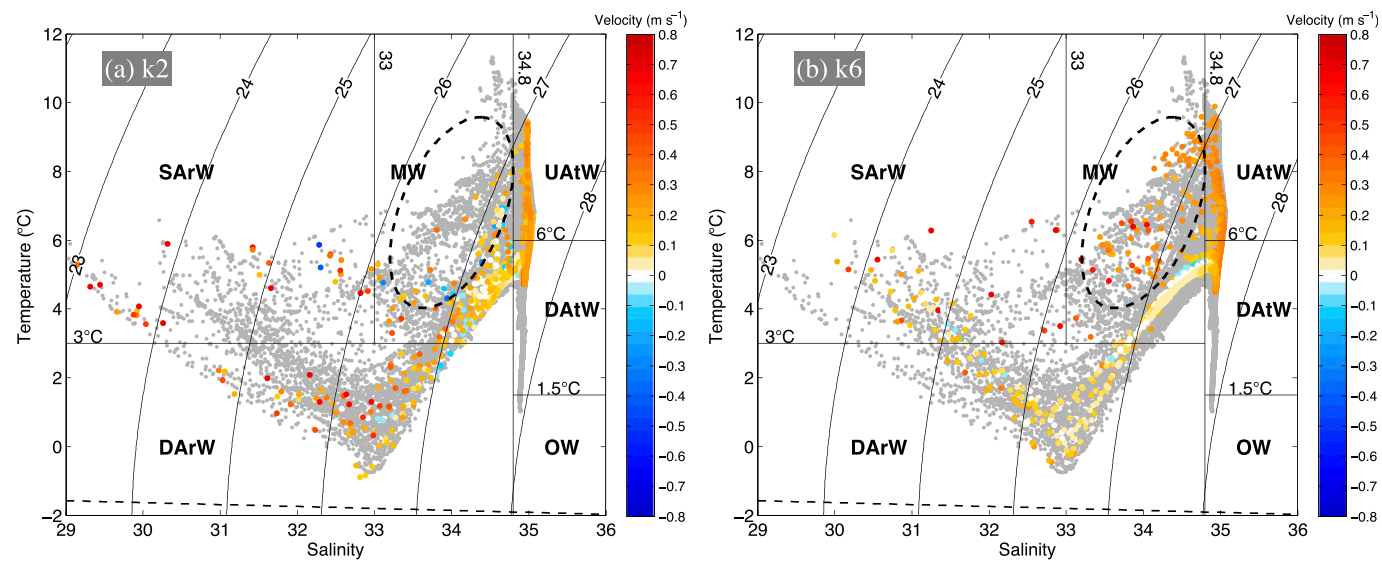

FIG. 8. A $\theta-S$ diagram where the values are color coded by absolute geostrophic velocity for (a) section $\mathrm{k} 2$ and (b) section k6. The gray dots are all of the hydrographic data obtained during the survey. The dashed ellipse encompasses the mixing line between the Atlantic-origin water and SArW.

experiments (Whitehead and Miller 1979; Sutherland and Cenedese 2009). The inertial radius of the Greenland Coastal Current, based on the data in our study, is $\sim 8 \mathrm{~km}$, which is in line with the value reported by Bacon et al. (2002) for the EGCC. This is much smaller than the curvature of Cape Farewell $(\sim 40 \mathrm{~km})$, suggesting that the coastal current does not progress offshore because of this effect.

\section{c. Effect of topography}

The most obvious candidate appears to be the change in the topography of the shelf on the two sides of Cape Farewell. As seen in Fig. 3, the shelf widens on the west Greenland side. As explained in section 2b, we quantified this by computing the distance of the shelf break from the coast at each transect using the ship's echosounder data together with its radar information. This distance is compared to the cross-shelf position of the core of the coastal current in Fig. 10 (we omit sections $\mathrm{k} 1$ and $\mathrm{k} 8$ from the figure because $\mathrm{k} 1$ did not cross the shelf break, and we did not get a radar measurement of the coast at $\mathrm{k} 8$ ). One sees that the coastal current shifted nearly $50-\mathrm{km}$ offshore between sections $\mathrm{k} 5$ and $\mathrm{k} 6$ where it flowed adjacent to the shelf break before veering back onshore by roughly $10 \mathrm{~km}$ at section $\mathrm{k} 7$.

Inspection of the bathymetric contours in Fig. 3 suggests that a canyon cuts into the shelf just to the west of section $\mathrm{k} 5$, and that the $100-\mathrm{m}$ depth contour is directed offshore on the west side of the canyon. This prompts the question, does the coastal current simply follow the isobaths offshore at this location? Unfortunately, it is impossible to answer this question using the ETOPO2v2 bathymetry, as we found that it disagrees significantly from the actual bottom depth over much of the survey region. Note that the ETOPO2v2 data suggest that the coastal current veers offshore upstream of where the bathymetry bends offshore, implying a strong cross-shelf component at $\mathrm{k} 5$.

During a subsequent OSNAP cruise (in August 2016), we occupied two additional transects between $\mathrm{k} 5$ and $\mathrm{k} 6$. This allowed us to determine the precise displacement of the isobaths in this region, and in Fig. 10 we plot the location of the $150-\mathrm{m}$ isobath from $\mathrm{k} 5$ to $\mathrm{k} 6$. This offers supporting evidence that the coastal current does indeed follow the isobaths offshore, and that this is the primary reason for the separation of the current from the coast. While the 2016 data are the subject of another study, we note that the coastal current was observed to separate from the coast at the same location during that survey. Overall then, this implies that excursions of the coastal current toward the shelf break, driven by bathymetric changes on the shelf, could lead to "hot spots" where the shelf-basin exchange of freshwater and other properties is enhanced. However, to identify such locations, accurate bathymetric data are required.

\section{Potential vorticity considerations}

The observed interaction of WGCC and the shelfbreak current, leading to the offshore flux of freshwater on the west side of Cape Farewell, motivates us to consider the stability characteristics of the flow. Following previous studies (e.g., Pickart et al. 2005; Spall and Pedlosky 2008), we evaluate the Ertel potential vorticity $\Pi$,

$$
\Pi=\frac{1}{g} \omega_{a} \cdot \nabla b,
$$

where $\boldsymbol{\omega}_{a}$ denotes the vector of the absolute vorticity, $b=-g \rho / \rho_{0}$ is the buoyancy, and $\rho_{0}$ is the reference 


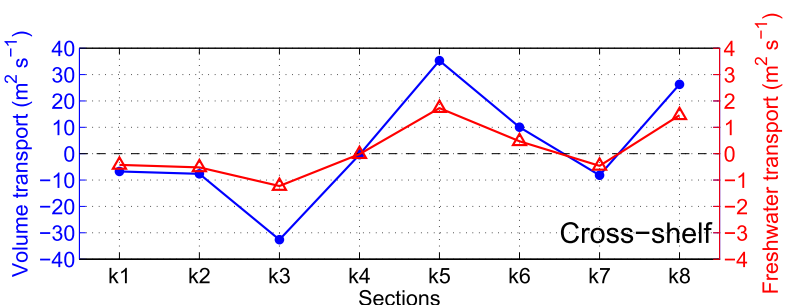

FIG. 9. Cross-shelf volume and freshwater transports per unit width of the coastal current for each transect.

density. Based on scale analysis for our application, (2) can be simplified to

$$
\Pi=\frac{f}{g} \frac{\partial b}{\partial z}-\frac{1}{g} \frac{\partial u}{\partial y} \frac{\partial b}{\partial z}+\frac{1}{g} \frac{\partial u}{\partial z} \frac{\partial b}{\partial y},
$$

where the $y$ direction is cross shelf, with positive directed seaward. The first term on the right-hand side of (3) is the stretching vorticity, and the second term is the relative vorticity term, which consists of the vertical component of relative vorticity and the vertical gradient of buoyancy. The third term is the tilting vorticity. Changes in the both vertical shear of velocity and the lateral buoyancy gradient affect the tilting term (see also Hall 1994). Here we focus on the top $100 \mathrm{~m}$ of the water column at section $\mathrm{k} 6$, delimited by the dashed green box in Fig. 7.

The different terms of $\Pi$ allow us to make assertions regarding the stability of the flow (Fig. 11). Overall, the Ertel potential vorticity is dominated by the stretching term (which is well matched with the pattern of buoyancy frequency; Fig. 6f). However, there are important differences due to the other components of the vorticity. The ratio of the relative vorticity term and stretching vorticity term (which is also the ratio of relative vorticity $\zeta$ and planetary vorticity $f$ ) shows large values of both the negative and positive relative vorticity on the anticyclonic and cyclonic sides of the coastal current, respectively. Such high values, exceeding $0.5 f$, suggest that the current is nonlinear and may be subject to barotropic instability (e.g., Pickart et al. 2005). The ratio of the tilting vorticity to stretching vorticity shows large negative values near the core of the current where the isopycnals are steeply sloped, corresponding to the hydrographic front between the Arctic- and Atlanticorigin water (Fig. 6d). Together with the negative values of the relative vorticity term, this results in a tendency of negative $\Pi$ in the core of the coastal current.

A necessary condition for baroclinic instability of a current is that the cross-stream gradient of $\Pi$ change sign within the domain (Magaldi et al. 2011). Inspection of Fig. 11a shows that this criterion is met for the coastal

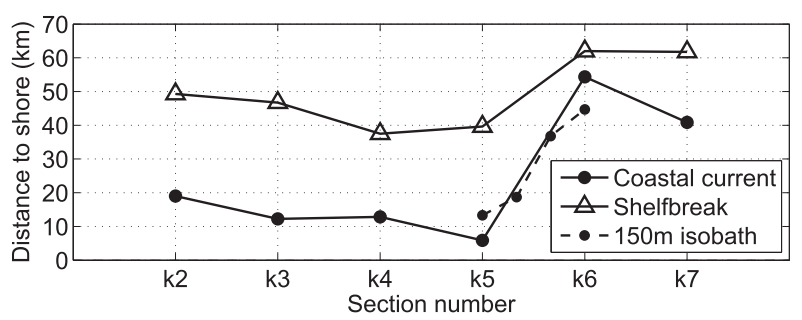

FIG. 10. Distance from the coast of the shelf break and the coastal current for transects $\mathrm{k} 2-\mathrm{k} 7$. Also plotted is the distance from the coast of the $150-\mathrm{m}$ isobath, determined from the ship's echosounder, for the region from section $\mathrm{k} 5$ to $\mathrm{k} 6$.

current. In particular, $\partial \Pi / \partial y<0$ on the shoreward side of the current near the surface, while $\partial \Pi / \partial y>0$ beneath this on the seaward side of the current. Furthermore, the potential vorticity tends to be negative in the core of the jet, suggesting that the current may be subject to symmetric instability (D'Asaro et al. 2011; Brearley et al. 2012). This type of instability occurs under conditions of strong vertical shear and weak vertical density gradients, which is associated with the strong negative values of tilting vorticity. These results suggest that both rapid (order of a few hours) and more slowly developing instabilities can occur, which would promote mixing of freshwater from the coastal current into the interior Labrador Sea, where the coastal current is located adjacent to the shelf break (recall the presence of the mixed water mass at section k6; Fig. 8b).

\section{Conclusions}

Data from a shipboard survey of the Cape Farewell region in summer 2014 were used to quantify the evolution of the Greenland Coastal Current as it navigates around the southern tip of Greenland. It was found that the current maintains its identity as it flows from the east side of the cape to the west side, instead of merging with the shelfbreak circulation, as has been suggested in previous studies. However, the bulk of the current detaches from the coast near the southern tip and shifts to the offshore edge of the shelf where it interacts with the shelfbreak current. A small branch of the coastal current remains inshore, and, when taking this into account, the total volume transport of the current (order of $1 \mathrm{~Sv}$ ) is conserved as it goes from the east Greenland shelf to the west Greenland shelf.

In contrast to this, the freshwater transport of the total coastal current system was found to decrease significantly where the main part of the flow transposed offshore. At section k6, on the west Greenland side of Cape Farewell, there was a large amount of freshwater found far offshore of the shelf break in the upper stratified 

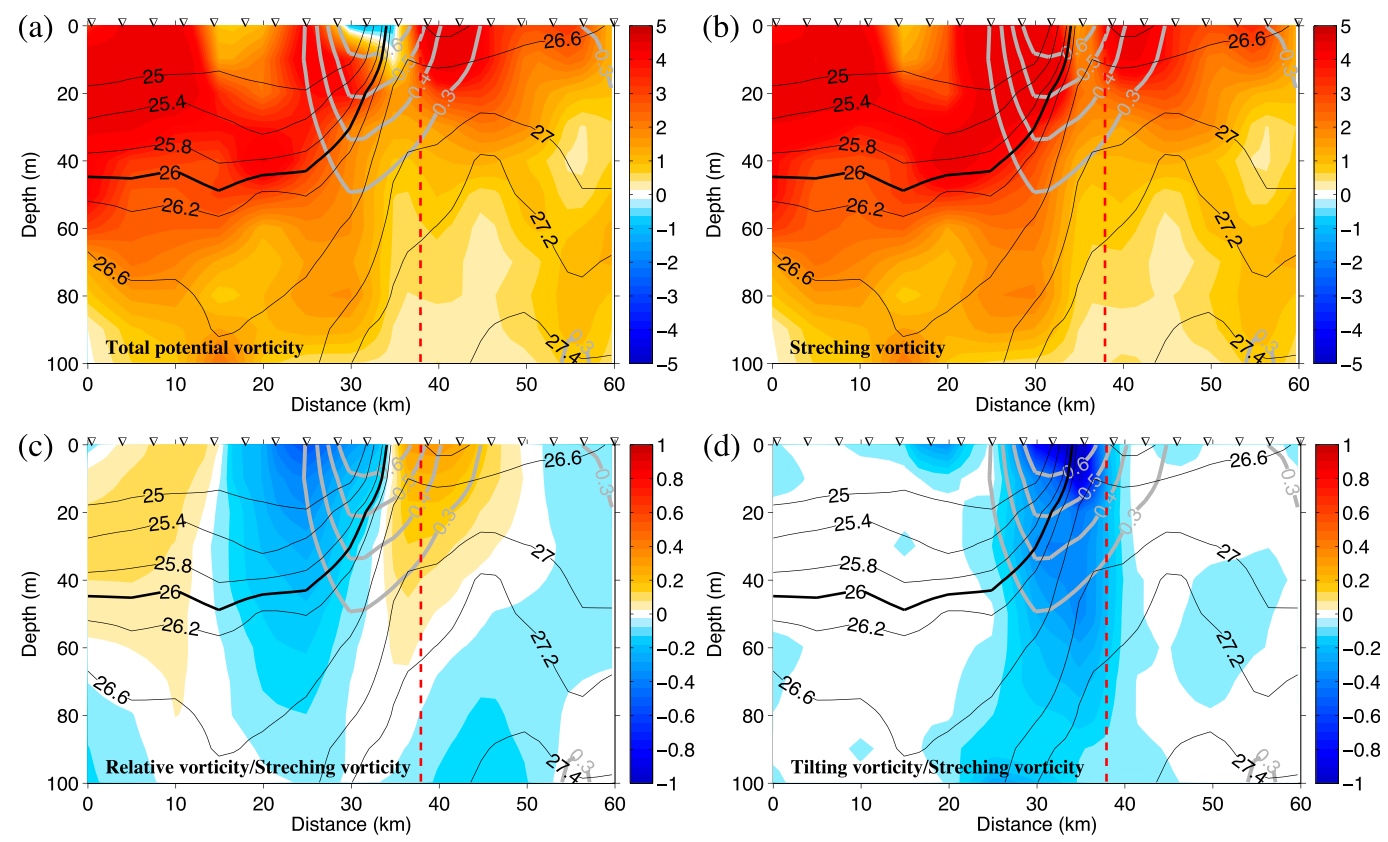

FIG. 11. Vertical sections of the components of the Ertel potential vorticity for section k6 for the region indicated by the dashed green box in Fig. 7. The thin black contours in each section are the potential density $\left(\mathrm{kg} \mathrm{m}^{-3}\right)$, and the thick gray contours are the along-shelf velocity $\left(\mathrm{m} \mathrm{s}^{-1}\right)$ showing the location of the coastal current. (a) Total potential vorticity $\left(\mathrm{m}^{-1} \mathrm{~s}^{-1} \times 10^{-9}\right.$; color). (b) Stretching vorticity $\left(\mathrm{m}^{-1} \mathrm{~s}^{-1} \times 10^{-9}\right.$; color). (c) The ratio of relative vorticity to stretching vorticity (color). (d) The ratio of tilting vorticity to stretching vorticity (color).

layer. A water mass analysis indicated that this water was a mixture between the surface Arctic-origin water on the shelf and the upper Atlantic-origin water on the slope. This indicates that there is substantial mixing where the coastal current and shelfbreak current flow side by side, leading to an offshore flux of freshwater, which likely explains the drop in freshwater transport of the coastal current.

We considered several mechanisms that might lead to the offshore transposition of the coastal current as it rounds Cape Farewell. The data suggest that wind is not the main driving factor, nor is the curvature of the coastline, which has a much larger radius of curvature than the inertial radius of the flow. We argue that the coastal current shifts offshore because of the change in topography near the southern tip of Greenland. Using accurate shipboard echosounder data, we demonstrated that the coastal current follows the isobaths as they bend offshore because of the widening of the shelf on the west side of Cape Farewell.

Evaluation of the potential vorticity structure of the coastal current, where it flows adjacent to the shelf break, allowed us to make assertions regarding the stability of the flow. The change in sign of the lateral gradient of potential vorticity with depth implies that the coastal current is baroclinically unstable. The large values of relative vorticity (exceeding $0.5 f$ ) suggest that the flow may be barotropically unstable as well. In addition, the large negative values of the tilting vorticity lead to the tendency of negative potential vorticity in the core of the coastal current, indicating that the flow may be subject to fast-growing symmetric instability. This condition arises from the strong vertical shear of velocity and the weak vertical density gradients associated with the sharp hydrographic front between the Arctic-origin shelf water and Atlantic-origin slope water.

The combination of the coastal current veering offshore to the shelf break on the west side of Cape Farewell in conjunction with the instability of the flow can explain the conditions leading to the off-shelf flux of freshwater in this region. Such a freshwater flux into the basin could impact the occurrence of convection in the Labrador Sea, both by leading to a stratified cap that would inhibit overturning and by influencing the restratification after the occurrence of convection. The impact is made greater by the fact that the coastal current carries the freshest, most buoyant water from the north, including meltwater and runoff from the Greenland ice sheet. It would be interesting to identify other areas along west Greenland where the coastal current may be diverted to the edge of the shelf to determine if there are additional "optimal" source regions for freshwater to enter the interior. It would also be enlightening to quantify the seasonal hydrographic and stability characteristics of the 
West Greenland Coastal Current. Toward this end, a mooring array is currently deployed west of Cape Farewell across the continental slope and outer shelf as part of OSNAP. Analysis of these data are currently underway.

Acknowledgments. The authors wish to thank the crew of the R/V Knorr for their efforts in obtaining the data used in this study, as well as the watchstanders on the scientific team. Carolina Nobre processed the CTD data at sea, and Leah McRaven calibrated the data postcruise. Funding for this project was provided by the National Science Foundation under Grant OCE-1259618.

\section{REFERENCES}

Bacon, S., G. Reverdin, I. G. Rigor, and H. M. Snaith, 2002: A freshwater jet on the east Greenland shelf. J. Geophys. Res., 107, 3068, https://doi.org/10.1029/2001JC000935.

—, A. Marshall, N. P. Holliday, Y. Aksenov, and S. R. Dye, 2014: Seasonal variability of the East Greenland Coastal Current. $J$. Geophys. Res. Oceans, 119, 3967-3987, https://doi.org/10.1002/ 2013JC009279.

Bailey, D. A., P. B. Rhines, and S. Häkkinen, 2005: Formation and pathways of North Atlantic Deep Water in a coupled iceocean model of the Arctic-North Atlantic Oceans. Climate Dyn., 25, 497-516, https://doi.org/10.1007/s00382-005-0050-3.

Brearley, J. A., R. S. Pickart, H. Valdimarsson, S. Jonsson, R. W. Schmitt, and T. W. N. Haine, 2012: The east Greenland boundary current system south of Denmark Strait. Deep-Sea Res. I, 63, 1-19, https://doi.org/10.1016/j.dsr.2012.01.001.

Buch, E., 2000: A monograph on the physical oceanography of the Greenland waters. Danish Meteorological Institute Scientific Rep. 00-12, 410 pp.

_ 2002: Present oceanographic conditions in Greenland waters. Danish Meteorological Institute Scientific Rep. 02-02, 39 pp.

Centurioni, L. R., and W. J. Gould, 2004: Winter conditions in the Irminger Sea observed with profiling floats. J. Mar. Res., 62 , 313-336, https://doi.org/10.1357/0022240041446209.

Cuny, J., P. B. Rhines, P. P. Niiler, and S. Bacon, 2002: Labrador Sea boundary currents and the fate of the Irminger Sea water. J. Phys. Oceanogr., 32, 627-647, https://doi.org/10.1175/15200485(2002)032<0627:LSBCAT>2.0.CO;2.

D'Asaro, E., C. Lee, L. Rainville, R. Harcourt, and L. Thomas, 2011: Enhanced turbulence and energy dissipation at ocean fronts. Science, 332, 318-322, https://doi.org/10.1126/science.1201515.

Dickson, R. R., and J. Brown, 1994: The production of North Atlantic Deep Water: Sources, rates, and pathways. J. Geophys. Res., 99, 12 319-12341, https://doi.org/10.1029/94JC00530.

— , B. Rudels, S. Dye, M. Karcher, J. Meincke, and I. Yashayaev, 2007: Current estimates of freshwater flux through Arctic and subarctic seas. Prog. Oceanogr., 73, 210-230, https://doi.org/ 10.1016/j.pocean.2006.12.003.

Egbert, G. D., and S. Y. Erofeeva, 2002: Efficient inverse modeling of barotropic ocean tides. J. Atmos. Oceanic Technol., 19, 183-204, https://doi.org/10.1175/1520-0426(2002)019<0183: EIMOBO $>2.0 . \mathrm{CO} ; 2$.

Firing, E., and J. M. Hummon, 2010: Ship-mounted acoustic Doppler current profilers. The GO-SHIP Repeat Hydrography Manual: A Collection of Expert Reports and Guidelines, E. M. Hood, C. L. Sabine, and B. M. Sloyan, Eds., ICPO Publication Series,
No. 134, International CLIVAR Project Office, 11 pp., https:// www.go-ship.org/Manual/Firing_SADCP.pdf.

Fratantoni, P. S., and R. S. Pickart, 2007: The western North Atlantic shelfbreak current system in summer. J. Phys. Oceanogr., 37, 2509-2533, https://doi.org/10.1175/JPO3123.1.

Friedrich, H., M.-N. Houssais, D. Quadfasel, and B. Rudels, 1995: On Fram Strait water masses. Extended Abstracts, Nordic Seas Symp., Hamburg, Germany, University of Hamburg, 69-72.

Haine, T. W. N., and Coauthors, 2015: Arctic freshwater export: Status, mechanisms, and prospects. Global Planet. Change, 125, 13-35, https://doi.org/10.1016/j.gloplacha.2014.11.013.

Hall, M. M., 1994: Synthesizing the Gulf Stream thermal structure from XBT data. J. Phys. Oceanogr., 24, 2278-2287, https://doi.org/ 10.1175/1520-0485(1994)024<2278:STGSTS > 2.0.CO;2.

Hanna, E., and Coauthors, 2008: Increased runoff from melt from the Greenland ice sheet: A response to global warming. J. Climate, 21, 331-341, https://doi.org/10.1175/2007JCLI1964.1.

Harden, B. E., F. Straneo, and D. A. Sutherland, 2014: Moored observations of synoptic and seasonal variability in the East Greenland Coastal Current. J. Geophys. Res. Oceans, 119, 8838-8857, https://doi.org/10.1002/2014JC010134.

Hátún, H., C. C. Eriksen, and P. B. Rhines, 2007: Buoyant eddies entering the Labrador Sea observed with gliders and altimetry. J. Phys. Oceanogr., 37, 2838-2854, https://doi.org/10.1175/2007JPO3567.1.

Håvik, L., R. S. Pickart, K. Våge, D. Torres, A. M. Thurnherr, A. Beszczynska-Möller, W. Walczowski, and W.-J. von Appen, 2017: Evolution of the East Greenland Current from Fram Strait to Denmark Strait: Synoptic measurements from summer 2012. J. Geophys. Res. Oceans, 122, 1974-1994, https://doi.org/10.1002/2016JC012228.

Holliday, N. P., A. Meyer, S. Bacon, S. G. Alderson, and B. de Cuevas, 2007: Retroflection of part of the East Greenland Current at Cape Farewell. Geophys. Res. Lett., 34, L07609, https://doi.org/10.1029/2006GL029085.

Jones, E. P., L. G. Anderson, S. Jutterström, and J. H. Swift, 2008: Sources and distribution of fresh water in the East Greenland Current. Prog. Oceanogr., 78, 37-44, https://doi.org/10.1016/ j.pocean.2007.06.003.

Klinger, B. A., 1994: Inviscid current separation from rounded capes. J. Phys. Oceanogr., 24, 1805-1811, https://doi.org/10.1175/15200485(1994)024<1805:ICSFRC>2.0.CO;2.

Lazier, J. R. N., 1980: Oceanographic conditions at Ocean Weather Ship Bravo, 1964-1974. Atmos.-Ocean, 18, 227-238, https:// doi.org/10.1080/07055900.1980.9649089.

Magaldi, M. G., T. W. N. Haine, and R. S. Pickart, 2011: On the nature and variability of the East Greenland Spill Jet: A case study in summer 2003. J. Phys. Oceanogr., 41, 2307-2327, https://doi.org/10.1175/JPO-D-10-05004.1.

Myers, P. G., 2005: Impact of freshwater from the Canadian Arctic Archipelago on Labrador Sea water formation. Geophys. Res. Lett., 32, L06605, https://doi.org/10.1029/2004GL022082.

— C. Donnelly, and M. H. Ribergaard, 2009: Structure and variability of the West Greenland Current in summer derived from 6 repeat standard sections. Prog. Oceanogr., 80, 93-112, https://doi.org/10.1016/j.pocean.2008.12.003.

Nilsson, J., G. Björk, B. Rudels, P. Winsor, and D. Torres, 2008: Liquid freshwater transport and Polar Surface Water characteristics in the East Greenland Current during the AO-02 Oden expedition. Prog. Oceanogr., 78, 45-57, https://doi.org/10.1016/j.pocean.2007.06.002.

Pickart, R. S., and M. A. Spall, 2007: Impact of Labrador Sea convection on the North Atlantic meridional overturning circulation. J. Phys. Oceanogr., 37, 2207-2227, https://doi.org/ 10.1175/JPO3178.1. 
D. J. Torres, and P. S. Fratantoni, 2005: The East Greenland Spill Jet. J. Phys. Oceanogr., 35, 1037-1053, https://doi.org/ 10.1175/JPO2734.1.

Rudels, B., H. J. Friedrich, and D. Quadfasel, 1999: The Arctic Circumpolar Boundary Current. Deep-Sea Res. II, 46, 10231062, https://doi.org/10.1016/S0967-0645(99)00015-6.

— E. E. Fahrbach, J. Meincke, G. Budéus, and P. Eriksson, 2002: The East Greenland Current and its contribution to the Denmark Strait overflow. ICES J. Mar. Sci., 59, 1133-1154, https://doi.org/10.1006/jmsc.2002.1284.

, G. Björk, J. Nilsson, P. Winsor, I. Lake, and C. Nohr, 2005: The interaction between waters from the Arctic Ocean and the Nordic seas north of Fram Strait and along the East Greenland Current: Results from the Arctic Ocean-02 Oden expedition. J. Mar. Syst., 55, 1-30, https://doi.org/10.1016/j.jmarsys.2004.06.008.

Rykova, T., F. Straneo, and A. S. Bower, 2015: Seasonal and interannual variability of the West Greenland Current System in the Labrador Sea in 1993-2008. J. Geophys. Res. Oceans, 120, 1318-1332, https://doi.org/10.1002/2014JC010386.

Schmidt, S., and U. Send, 2007: Origin and composition of seasonal Labrador Sea freshwater. J. Phys. Oceanogr., 37, 1445-1454, https://doi.org/10.1175/JPO3065.1.

Schmith, T., and C. Hansen, 2003: Fram Strait ice export during the nineteenth and twentieth centuries reconstructed from a multiyear sea ice index from southwestern Greenland. J. Climate, 16, 2782-2791, https://doi.org/10.1175/1520-0442(2003)016<2782: FSIEDT $>2.0 . \mathrm{CO} ; 2$.

Spall, M. A., and J. Pedlosky, 2008: Lateral coupling in baroclinically unstable flows. J. Phys. Oceanogr., 38, 1267-1277, https:// doi.org/10.1175/2007JPO3906.1.

Straneo, F., 2006: Heat and freshwater transport through the central Labrador Sea. J. Phys. Oceanogr., 36, 606-628, https://doi.org/ 10.1175/JPO2875.1.

Sutherland, D. A., and R. S. Pickart, 2008: The East Greenland Coastal Current: Structure, variability, and forcing. Prog. Oceanogr., 78, 58-77, https://doi.org/10.1016/j.pocean.2007.09.006.

— teraction of a buoyant coastal current with a canyon: Application to the East Greenland Current. J. Phys. Oceanogr., 39, 1258-1271, https://doi.org/10.1175/2008JPO4028.1.

, R. S. Pickart, E. P. Jones, K. Azetsu-Scott, A. J. Eert, and J. Ólafsson, 2009: Freshwater composition of the waters off southeast Greenland and their link to the Arctic Ocean. J. Geophys. Res., 114, C05020, https://doi.org/10.1029/ 2008JC004808.

Talley, L. D., and M. S. McCartney, 1982: Distribution and circulation of Labrador Sea water. J. Phys. Oceanogr., 12, 1189-1205, https://doi.org/10.1175/1520-0485(1982)012<1189: DACOLS $>2.0 . \mathrm{CO} ; 2$.

_ , J. L. Reid, and P. E. Robbins, 2003: Data-based meridional overturning streamfunctions for the global ocean. J. Climate, 16, 3213-3226, https://doi.org/10.1175/1520-0442(2003)016<3213: DMOSFT $>2.0 . \mathrm{CO} ; 2$.

Våge, K., R. S. Pickart, M. A. Spall, H. Valdimarsson, S. Jónsson, D. J. Torres, S. Østerhus, and T. Eldevik, 2011: Significant role of the north Icelandic jet in the formation of Denmark Strait overflow water. Nat. Geosci., 4, 723-727, https://doi.org/10.1038/ ngeo1234.

,,,--- G. Moore, H. Valdimarsson, D. J. Torres, S. Y. Erofeeva, and J. E. Ø. Nilsen, 2013: Revised circulation scheme north of the Denmark Strait. Deep-Sea Res. I, 79, 20-39, https://doi.org/10.1016/j.dsr.2013.05.007.

von Appen, W.-J., and Coauthors, 2014: The East Greenland Spill Jet as an important component of the Atlantic meridional overturning circulation. Deep-Sea Res. I, 92, 75-84, https://doi.org/ 10.1016/j.dsr.2014.06.002.

Whitehead, J. A., Jr., and A. R. Miller, 1979: Laboratory simulation of the gyre in the Alboran Sea. J. Geophys. Res., 84, 37333742, https://doi.org/10.1029/JC084iC07p03733.

Whitney, M. M., and R. W. Garvine, 2005: Wind influence on a coastal buoyant outflow. J. Geophys. Res., 110, C03014, https:// doi.org/10.1029/2003JC002261.

Wilkinson, D., and S. Bacon, 2005: The spatial and temporal variability of the East Greenland Coastal Current from historic data. Geophys. Res. Lett., 32, L24618, https://doi.org/10.1029/ 2005 GL024232.

Woodgate, R. A., K. Aagaard, and T. J. Weingartner, 2005: Monthly temperature, salinity, and transport variability of the Bering Strait through flow. Geophys. Res. Lett., 32, L04601, https://doi.org/10.1029/2004GL021880.

Yashayaev, I., H. M. van Aken, N. P. Holliday, and M. Bersch, 2007: Transformation of the Labrador Sea water in the subpolar North Atlantic. Geophys. Res. Lett., 34, L22605, https:// doi.org/10.1029/2007GL031812. 